\title{
SOCIO-MEDICAL STUDY OF ENURESIS AMONG DELINQUENT BOYS
}

\author{
BY \\ ZENA A. STEIN* AND M. W. SUSSER \\ Department of Social and Preventive Medicine, University of Manchester
}

Persistent enuresis, like apprehended juvenile crime, is common among poorly-housed and illeducated families, and uncommon among intact families of the well-to-do. (For the social distribution of enuresis see Harnack, 1953; Bloomfield and Douglas, 1956; Hallgren, 1956; Miller, Court, Walton, and Knox, 1960. For the social distribution of delinquency see Burt, 1947, 1952; Mannheim, 1948; Ferguson, 1952; Clinard, 1962.) The ecology of enuresis and of juvenile crime thus shows similarities, and some studies have suggested that enuresis is a frequent attribute of young delinquents (Healey and Bronner, 1936; Hirsch, 1937; Michaels and Goodman, 1939).

One could hope to find, in young offenders sent to approved schools, a prevalence of enuresis high enough to enable the relationship between enuresis and delinquency to be studied. Approved schools provide a population of children who have responded to their situations by repetitive criminal acts. The object of the present study was to discriminate, within the general background of factors associated with this "voluntary" response, with what special factors the repetitive involuntary response of bedwetting was associated.

Two hypotheses were given special consideration. First, the observations of workers such as Burlingham and Freud (1944), as well as our own, led us to pay special attention to relations between child and mother. In a family study we found that persistent bedwetting seemed to be connected with disturbance in a child's relations with its mother (Stein, Susser, and Wilson, 1965). Secondly, we thought it might be possible to distinguish qualities of temperament and behaviour characteristic of boys who were enuretic. Several studies provide evidence of a connexion between enuresis and nervous symptoms such as tics, nail-biting, and tantrums (Michaels and Goodman, 1939; Ekblad, 1948; Harnack, 1953; Hallgren, 1956).

* Holding a personal grant from the Medical Research Council. The field work was done during her tenure of a Fellowship from the Mental Health Research Fund.

\section{METHOD}

Our method was to determine the occurrence of enuresis within a large resident population of delinquent boys, and to search for differences between boys found to be enuretic and the rest. The approved schools in the vicinity of Manchester were selected for investigation. Girls were not studied, as in the one available school for girls numbers were too small for statistical analysis.

In this area boys destined for an approved school are usually admitted for a preliminary 3-week stay to a "classifying school". Here they are observed, examined, and assessed before being transferred to an approved school selected on the basis of this assessment. The classifying school provided us with systematic records for a large number of boys. The files included reports from probation officers and the courts, and from the psychologists and the school doctor. For each boy admitted during 1960, the history of bedwetting at home and of bedwetting observed in the school was taken from the routine records. Age at last birthday and intelligence test scores were also abstracted.

A detailed study was made of the files of all 78 boys recorded as enuretic at the classifying school during that year, and of 78 non-enuretic controls matched for age and date of admission. The control and the enuretic samples are younger than the total school population because enuresis is commoner among young boys. There is no reason to think that matching for date of admission influenced the composition of the control sample.

"Personality" ratings were also obtained from the records of the classifying school. The ratings were said to express staff opinion at an assessment meeting held towards the end of each boy's stay in the classifying school, and seemed to derive from observations of behaviour, rather than from interpretation of projective tests and intra-psychic processes. They were intended for the guidance of the approved schools to which the boys were to be sent, and were thus made without reference to our investigation of 
enuresis. All boys were not rated on all attributes (see Appendix 1) because the practice of the psychologists varied during the time of the study. Since cases and controls were matched for date of admission, the numbers and types of tests given to the two groups were almost identical.

Five approved schools for boys were visited in addition to the classifying school. At each school the number of bedwetters and the age-composition of the school population was noted, and we discussed with the staff their own observations on enuresis.

Some material gathered in other phases of a sociomedical study of enuresis has been used in this paper for comparison. The main part of our data is drawn from records, and despite detailed and systematic record keeping this study suffers from the limitations inherent in such data.

\section{RESULTS}

\section{Prevalence}

The prevalence of enuresis among boys in the classifying school during 1960 is compared with that among schoolboys living in their own homes in Leigh, a predominantly working-class Lancashire town (Table I). The Leigh figures are based on direct questioning of the parents of a random sample of boys attending day schools during 1960.

TABLE I

PREVALENCE OF ENURESIS IN BOYS IN CLASSIFYING SCHOOL COMPARED WITH DAY SCHOOL BOYS

\begin{tabular}{|c|c|c|c|c|c|c|}
\hline \multirow{2}{*}{ Age (yrs) } & \multicolumn{2}{|c|}{$\begin{array}{c}\text { Classifying } \\
\text { School }\end{array}$} & \multicolumn{2}{|c|}{ Day School } & \multirow{2}{*}{$(\mathrm{d} . f .=1)$} & \multirow{2}{*}{$\mathbf{P}$} \\
\hline & \begin{tabular}{|c|}
$\begin{array}{c}\text { No. } \\
\text { of } \\
\text { Boys }\end{array}$ \\
\end{tabular} & $\begin{array}{c}\text { Per- } \\
\text { centage } \\
\text { Enuretic }\end{array}$ & $\begin{array}{c}\text { No. } \\
\text { of } \\
\text { Boys }\end{array}$ & $\begin{array}{c}\text { Per- } \\
\text { centage } \\
\text { Enuretic }\end{array}$ & & \\
\hline $\begin{array}{r}9-10 \\
11-12 \\
13-14 \\
15-16\end{array}$ & $\begin{array}{r}30 \\
124 \\
100 \\
285\end{array}$ & $\begin{array}{r}20 \cdot 0 \\
24 \cdot 2 \\
8 \cdot 3 \\
4 \cdot 9\end{array}$ & $\begin{array}{l}196 \\
391 \\
100 \\
100\end{array}$ & $\begin{array}{l}7 \cdot 7 \\
5.9 \\
1.0 \\
1.0\end{array}$ & $\begin{array}{r}3 \cdot 355 \\
32 \cdot 237 \\
5 \cdot 406 \\
2 \cdot 071\end{array}$ & $\begin{array}{l}<0.10>0.05 \\
<0.001 \\
<0.05>0.02 \\
<0.20>0.10\end{array}$ \\
\hline
\end{tabular}

The prevalence is higher in the boys in the classifying school at each age group. Adding the $\chi^{2}$ 's, gives $\chi^{2}=43.069$ (d.f. $\left.=4\right) ; P<0.001$.

The rates of enuresis in the classifying school are significantly higher than rates for boys living at home and attending day schools. We do not believe that the rates for boys living at home are less because of under-reporting, since they are higher than those for comparable surveys. Table II shows that the rates in the classifying school and in the approved schools hardly differed. It establishes that enuresis is not merely a temporary phenomenon affecting boys passing through the classifying school but that it persists at high prevalence in the more stable approved school population.

Two boarding schools were investigated as a control for the factor of schooling away from home.
TABle II

PREVALENCE OF ENURESIS IN BOYS IN CLASSIFYING SCHOOL AND APPROVED SCHOOLS

\begin{tabular}{c|c|c|c|c}
\hline \multirow{2}{*}{ Age (yrs) } & \multicolumn{3}{|c|}{ School } \\
\cline { 2 - 5 } & \multicolumn{2}{|c|}{ Classifying } & \multicolumn{2}{|c}{ Approved } \\
\cline { 2 - 5 } & No. of Boys & $\begin{array}{c}\text { Percentage } \\
\text { Enuretic }\end{array}$ & No. of Boys & $\begin{array}{c}\text { Percentage } \\
\text { Enuretic }\end{array}$ \\
\hline $9-10$ & 30 & $20 \cdot 0$ & 12 & $\begin{array}{c}\text { Data } \\
\text { unreliable } \\
22 \cdot 4 \\
11-12\end{array}$ \\
$13-14$ & 124 & $24 \cdot 1$ & 85 & $9 \cdot 2$ \\
$15-16$ & 287 & $8 \cdot 3$ & 130 & $6 \cdot 3$ \\
\hline
\end{tabular}

Few cases were reported among the boarders. The headmasters stated that this was not owing to the exclusion of enuretic boys, but it is likely that the parents of enuretic children tend to avoid placing them in boarding schools.

\section{General Social Characteristics}

Enuretic boys were compared with controls over a wide range of qualities set out in Appendix I. There were no significant differences between enuretic boys and controls in social class: among the fathers of all the boys, 75 per cent. were in Social Class IV and V, more than double the expected proportion for Lancashire. Only one of the 78 cases and one of the 78 controls had attended a grammar school.

Sibships tended to be large, the mean being $5 \cdot 6$, but there was no significant difference in mean sibship size between enuretic boys and controls, nor were there significant differences in the proportion of representatives of any particular family size, tested by the $K \times 2 \chi^{2}$ test.

Criminal records were found significantly more often among the sibs of enuretic boys (Table III).

Forty enuretic boys, compared with 25 controls, came from families in which at least one sib had had a

TABLE III

OFFENDERS* IN SIBSHIPS OF ENURETIC BOYS AND CONTROLS

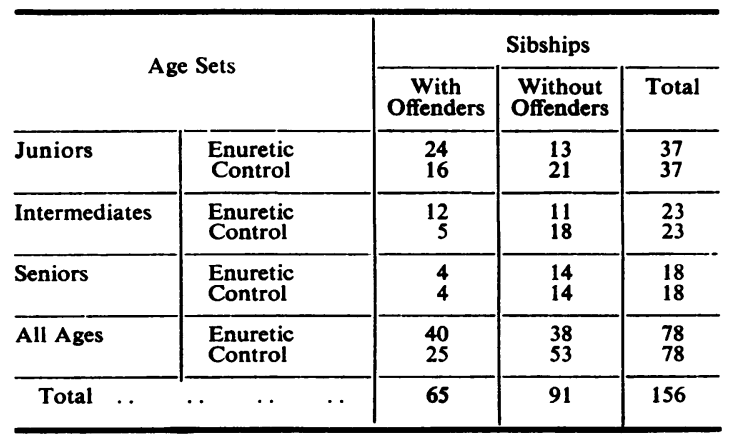

$\chi^{2}=5 \cdot 17$ (applying Yates' correction) $\mathrm{P}<0.05$ (d.f. $=1$ ).

* Offenders' in this case excludes the subjects of the present study. 
conviction. The breakdown of Table III into age groups shows that senior boys did not contribute to this result.

\section{Family Deprivation}

Several kinds of data were available which could be taken as providing evidence of family deprivation (see Table V and Appendix I).

Loss of Mother through Desertion, Separation, or Divorce.-Eight enuretic boys had lost their mothers through desertion, separation, or divorce, as against one control (Table IV). This result was significant $(\mathrm{P}<0.05)$.

TABLE IV

LOSS OF MOTHER THROUGH DESERTION, SEPARATION, OR DIVORCE

\begin{tabular}{r|c|c|c|c}
\hline \multirow{2}{*}{ Age (yrs) } & \multicolumn{2}{|c|}{ Enuretic } & \multicolumn{2}{c}{ Control } \\
\cline { 2 - 4 } & $\begin{array}{c}\text { Maternal } \\
\text { Loss }\end{array}$ & Total & $\begin{array}{c}\text { Maternal } \\
\text { Loss }\end{array}$ & Total \\
\hline $9-12$ & 1 & 37 & 0 & 37 \\
$13-14$ & 3 & 23 & 0 & 23 \\
$15-16$ & 4 & 18 & 1 & 18 \\
\hline All Ages & 8 & 78 & 1 & 78 \\
\hline
\end{tabular}

$P<\cdot 035$ by binomial test for matched pairs. There were 69 like pairs; of the nine unlike pairs, eight enuretic boys and one control had lost their mothers.

Other Indices of Family Deprivation.-By all remaining indices of family deprivation available to us, there were no significant differences between the experiences of enuretic boys and controls (Table V).

TABLE V

INDICES OF PARENTAL DEPRIVATION* IN ENURETIC BOYS AND CONTROLS

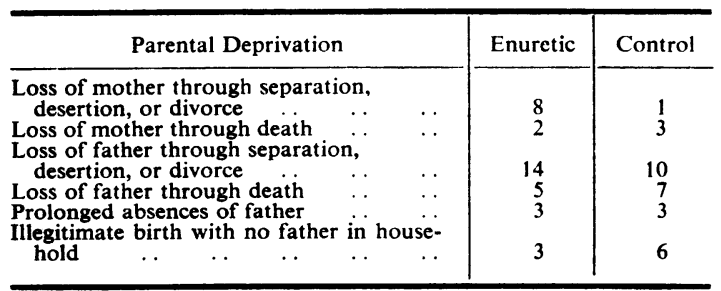

- Some boys experienced more than one form of deprivation.

\section{Behaviour Traits}

The qualities of behaviour, for which boys were rated on a five-point scale, are shown in Appendix I. Boys were not all rated for all qualities because from time to time the qualities scored at assessment meetings changed. In comparison with controls, enuretic boys tended to be rated submissive, and lacking in dominance, capacity for leadership, and interest in sex (Table VI, opposite). These were the only traits in which the cases and controls differed significantly.

On commonsense grounds submissiveness, lack of leadership, and lack of dominance might be considered as components of a single complex. Amongst enuretic boys the three traits were significantly associated ( $P \leqslant 0.001$; see Appendix II). Amongst controls none was rated submissive. The remaining two traits were again significantly associated (P<0.05; see Appendix II).

When these traits were treated in combination, significant differences were found between enuretic boys and controls. Seven enuretic boys scored low on all three traits, as against no controls; eight enuretic boys and six controls scored low on two of the three traits (Table VII, opposite.)

Of the boys whose mothers had left them, only three had been rated for behaviour traits and all scored low on two traits (dominance and leadership). The trend for this very small number of boys seemed to differ from that for boys with no known parental deprivations. Boys with paternal loss seemed to have an intermediate distribution of traits.

\section{Intelligence Test Scores}

Enuretic boys scored significantly lower on the Wechsler performance and full-scale intelligence tests. The main contributions to the difference were made by the senior boys, who scored significantly lower on all parts of the test, including the verbal test. In the younger age groups enuretic boys scored lower, but not significantly so, in the performance and full-scale tests, and scored no less than the controls in the verbal test (Table VIII, opposite).

\section{CRIMINAL ReCORD}

The criminal records of enuretic boys differed significantly from those of controls in only two respects (see Appendix I). First, they committed breaking and entering together with larceny less often than controls. Seventeen enuretic boys had been found guilty of both larceny and breaking and entering, against thirty controls $\left(\chi^{2}=5 \cdot 5 ; 1\right.$ d.f.; $P<0.05)$. This applies to the offence which led to committal to approved school. There was no such difference in the first offence (see Appendix I).

Secondly, enuretic boys had been on probation before admission more often than had controls; seventy of 78 enuretic boys compared with 59 controls had experienced probation $\left(\chi^{2}=5 \cdot 42 ; 1\right.$ d.f.; $\mathrm{P}<0.05$ ).

\section{BedWetting IN the Sickbay}

In four of the five approved schools visited, the matron or housemother reported, on questioning, that when enuretic boys slept in the sickbay they 
TABLE VI

BEHAVIOUR TRAITS* COMPARED IN ENURETIC BOYS AND CONTROLS

\begin{tabular}{|c|c|c|c|c|c|c|c|c|c|c|c|}
\hline \multirow{2}{*}{ Trait } & \multirow{2}{*}{\multicolumn{8}{|c|}{ Series }} & \multicolumn{3}{|c|}{ Rating } \\
\hline & & & & & & & & & Low & High & Total \\
\hline \multirow[t]{2}{*}{ (A) Sex Interest } & $\begin{array}{l}\text { Enuretic .. } \\
\text { Control .. }\end{array}$ & $\cdots$ & $\begin{array}{l}\cdots \\
\cdots \\
\end{array}$ & $\ddot{*}$ & 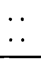 & $\begin{array}{l}\cdots \\
\cdots\end{array}$ & $\begin{array}{l}\cdots \\
\cdots\end{array}$ & $\begin{array}{l}\cdots \\
\cdots\end{array}$ & 11 & $\begin{array}{l}20 \\
30 \\
\end{array}$ & $\begin{array}{l}31 \\
30\end{array}$ \\
\hline & \multicolumn{3}{|c|}{$x^{2}=10.697,1$ d.f. $P<0.01$} & $\cdots$ & $\cdots$ & $\cdots$ & $\cdots$ & $\cdots$ & 11 & 50 & 61 \\
\hline \multirow[t]{2}{*}{ (B) Submissiveness } & $\begin{array}{l}\text { Enuretic .. } \\
\text { Control .. }\end{array}$ & 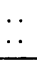 & $\cdots$ & 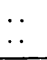 & $\cdots$ & 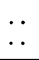 & $\cdots$ & $\begin{array}{l}\cdots \\
\cdots\end{array}$ & $\begin{array}{l}7 \\
0\end{array}$ & $\begin{array}{l}24 \\
30\end{array}$ & $\begin{array}{l}31 \\
30\end{array}$ \\
\hline & \multicolumn{8}{|c|}{$\mathbf{P}<0.01$ (after Finney, Latscha, Bennett, and Hsu, 1963) .. } & 7 & 54 & 61 \\
\hline \multirow[t]{2}{*}{ (C) Leadership } & $\begin{array}{l}\text { Enuretic .. } \\
\text { Control .. }\end{array}$ & $\begin{array}{l}\cdots \\
\cdots\end{array}$ & $\begin{array}{l}\cdots \\
\cdots\end{array}$ & $\begin{array}{l}\cdots \\
\cdots\end{array}$ & $\begin{array}{l}\cdots \\
\cdots\end{array}$ & $\cdots$ & 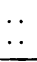 & $\begin{array}{l}\cdots \\
\cdots\end{array}$ & $\begin{array}{l}21 \\
12 \\
\end{array}$ & $\begin{array}{l}10 \\
18 \\
\end{array}$ & $\begin{array}{l}31 \\
30 \\
\end{array}$ \\
\hline & \multicolumn{4}{|c|}{$x^{2}=3 \cdot 674,1$ d.f. $P<0 \cdot 10>0.05$} & $\cdots$ & $\cdots$ & $\cdots$ & $\cdots$ & 33 & 28 & 61 \\
\hline \multirow[t]{2}{*}{ (D) Dominance } & $\begin{array}{l}\text { Enuretic .. } \\
\text { Control } \ldots\end{array}$ & $\ddot{*}$ & $\begin{array}{l}\cdots \\
\cdots \\
\end{array}$ & $\begin{array}{l}\cdots \\
\cdots \\
\end{array}$ & $\begin{array}{l}\cdots \\
\cdots \\
\end{array}$ & 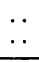 & $\begin{array}{l}\cdots \\
\cdots\end{array}$ & $\ddot{*}$ & $\begin{array}{r}15 \\
7\end{array}$ & $\begin{array}{l}16 \\
23\end{array}$ & $\begin{array}{l}31 \\
30\end{array}$ \\
\hline & \multicolumn{4}{|c|}{$x^{2}=3 \cdot 135,1$ d.f. $P<0 \cdot 10>0.05$} & $\cdots$ & $\cdots$ & $\cdots$ & $\cdots$ & 22 & 39 & 61 \\
\hline
\end{tabular}

- All the traits had been scored on a 5-point scale. We reduced this to a 2-point scale. Boys scoring 1 or 2 for leadership, dominance, or sex interest were rated "low" for that trait, while those scoring 3, 4, or 5 were rated "high". Scores of 4 or 5 for submissiveness were classified as "low", and scores of 1,2 , or 3 as "high", on the assumption that it bears an inverse relationship to the other qualities scaled.

TABLE VII

CLUSTERING OF TRAITS IN RATED BOYS

\begin{tabular}{|c|c|c|c|c|c|c|c|c|c|}
\hline \multirow{2}{*}{\multicolumn{4}{|c|}{ Rating }} & \multirow{3}{*}{$\begin{array}{c}3 \text { Low } \\
\text { Scores }\end{array}$} & \multirow{3}{*}{$\begin{array}{c}2 \text { Low } \\
\text { Scores } \\
8 \\
6\end{array}$} & \multirow{3}{*}{$\begin{array}{c}1 \text { Low } \\
\text { Score }\end{array}$} & \multirow{3}{*}{$\begin{array}{c}\begin{array}{c}\text { No Low } \\
\text { Scores }\end{array} \\
10 \\
17\end{array}$} & \multicolumn{2}{|c|}{ Total } \\
\hline & & & & & & & & \multirow{2}{*}{$\begin{array}{c}\text { Rated } \\
31 \\
30\end{array}$} & \multirow{2}{*}{$\begin{array}{c}\text { Not Rated } \\
47 \\
48\end{array}$} \\
\hline By Enuresis & $\begin{array}{ll}\text { Enuretic } & \ldots \\
\text { Control } & \ldots\end{array}$ & $\begin{array}{l}\cdots \\
\cdots\end{array}$ & $\begin{array}{l}\cdots \\
\cdots\end{array}$ & & & & & & \\
\hline By Parental Deprivation & $\begin{array}{l}\text { Mother left } \\
\text { Mother died } \\
\text { Father left } \\
\text { Father died } \\
\text { Illegitimate } \\
\text { No known loss }\end{array}$ & $\begin{array}{l}\cdots \\
\cdots \\
\cdots \\
\cdots \\
\cdots\end{array}$ & $\begin{array}{l}\ldots \\
\cdots \\
\cdots \\
\cdots \\
\cdots\end{array}$ & $\begin{array}{l}0 \\
0 \\
1 \\
0 \\
0 \\
6\end{array}$ & $\begin{array}{l}3 \\
0 \\
2 \\
2 \\
0 \\
7\end{array}$ & $\begin{array}{l}0 \\
0 \\
2 \\
1 \\
1 \\
5\end{array}$ & $\begin{array}{r}0 \\
2 \\
5 \\
2 \\
0 \\
22\end{array}$ & $\begin{array}{r}3 \\
2 \\
10 \\
5 \\
1 \\
40\end{array}$ & $\begin{array}{r}6 \\
3 \\
20 \\
6 \\
8 \\
52\end{array}$ \\
\hline & Total & . & $\ldots$ & 7 & 14 & 9 & 31 & 61 & 95 \\
\hline
\end{tabular}

TABLE VIII

INTELLIGENCE TEST SCORES

(WISC) IN ENURETIC BOYS AND CONTROLS

\begin{tabular}{|c|c|c|c|c|c|c|c|c|c|}
\hline \multirow{2}{*}{ Age Sets } & \multirow{2}{*}{\multicolumn{5}{|c|}{ Series }} & \multicolumn{3}{|c|}{ Mean Scores } & \multirow{2}{*}{ No. of Boys } \\
\hline & & & & & & Verbal & Performance & Full-scale & \\
\hline Junior & $\begin{array}{l}\text { Enuretic } \\
\text { Control }\end{array}$ & $\begin{array}{l}\cdots \\
\cdots\end{array}$ & $\begin{array}{l}\cdots \\
\cdots\end{array}$ & $\ddot{*}$ & $\begin{array}{l}\cdots \\
\cdots\end{array}$ & $\begin{array}{l}91 \cdot 8 \\
92 \cdot 5\end{array}$ & $\begin{array}{l}91 \cdot 6 \\
97 \cdot 0\end{array}$ & $\begin{array}{l}90 \cdot 8 \\
94 \cdot 1\end{array}$ & $\begin{array}{l}37 \\
37\end{array}$ \\
\hline Intermediate & $\begin{array}{l}\text { Enuretic } \\
\text { Control }\end{array}$ & $\begin{array}{l}\cdots \\
\cdots\end{array}$ & 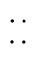 & $\ddot{*}$ & $\cdots$ & $\begin{array}{l}85 \cdot 8 \\
85 \cdot 2\end{array}$ & $\begin{array}{l}90 \cdot 3 \\
95 \cdot 8\end{array}$ & $\begin{array}{l}86 \cdot 7 \\
89 \cdot 0\end{array}$ & $\begin{array}{l}23 \\
23\end{array}$ \\
\hline Senior & $\begin{array}{l}\text { Enuretic } \\
\text { Control }\end{array}$ & $\begin{array}{l}\cdots \\
\cdots\end{array}$ & $\begin{array}{l}\cdots \\
\cdots\end{array}$ & $\ddot{*}$ & $\begin{array}{l}\cdots \\
\ldots\end{array}$ & $\left.\begin{array}{r}93 \cdot 3 \\
104 \cdot 3\end{array}\right\}$ & $\left.\begin{array}{r}93 \cdot 7 \\
104 \cdot 6\end{array}\right\}^{\dagger}$ & $\left.\begin{array}{r}92.8 \\
104.8\end{array}\right\}^{t}$ & $\begin{array}{l}18 \\
18\end{array}$ \\
\hline All Ages & $\begin{array}{l}\text { Enuretic } \\
\text { Control }\end{array}$ & $\ddot{m}$ & $\ddot{x}$ & $\ddot{m}$ & $\cdots$ & $\begin{array}{l}90 \cdot 4 \\
93 \cdot 2\end{array}$ & $\begin{array}{l}91 \cdot 7 \ddagger \\
98 \cdot 4\end{array}$ & $\begin{array}{l}90 \cdot 1 t \\
95 \cdot 2\end{array}$ & $\begin{array}{l}78 \\
78\end{array}$ \\
\hline
\end{tabular}

The difference between the means has been tested by the $t$ test, applying Bessel's correction.

rarely wet their beds. No opinion was ventured by the matron of the fifth school. To test this impression, we turned to the classifying school where records of bedwetting had been kept, and examined the records of 100 consecutive admissions to the sickbay during 1960. Fifteen of the boys admitted were known to be bedwetters in their usual sleeping-quarters, where on average they wet four nights per week. In the sickbay, only one boy had wet the bed, and on only one occasion. The average stay in the sickbay was 7 nights. Thus sixty incidents of bedwetting might have been expected, and only one occurred. 


\section{Discussion}

This study establishes that enuresis has a high prevalence among boys in approved schools.

The social and cultural background of enuretic and non-enuretic delinquent boys was broadly similar, in such matters as family occupation and education. The boys could be differentiated in the two main respects of relations with mothers and of attributes of behaviour.

Enuretic boys had lost mothers through desertion, separation, and divorce more often than controls, that is, through a positive act of departure by the mother. The departure of mothers can well bear, for their children, the psychological interpretation of rejection, and this may be the significant element. Maternal rejection is a less likely concomitant of the forms of loss which showed no association with enuresis, namely separation of the subject from home, death of the mother, loss of the father.

Enuretic boys could also be differentiated from controls in attributes of behaviour. They had less often committed the crime of breaking and entering, and they tended to be rated submissive and lacking in dominance, leadership, and interest in sex. We have shown that at least three of these qualities are associated with each other and may reflect facets of a single element. Conceivably, the association of these traits of waking behaviour with nocturnal enuresis could be the result of enuresis. Both the traits and the enuresis, however, could have a common source, and in our view a more likely one, in a maternal factor.

\section{ENURESIS AND DELINQUENCY}

There are similarities and divergences in the circumstances in which enuresis and delinquency occur. The similarities reside in their general social distribution. The differences are found in more specific personal and family attributes. Thus bedwetting is an involuntary act during sleep, apparently associated with timid rather than aggressive behaviour, and with insecure maternal relations. By contrast, delinquency is "acting-out" during waking hours, with an element of aggression turned upon the family or the outside world, and it is associated with problems of paternal relations. In the families of boys who commit crimes, deviant or absent fathers are a prominent feature (Glueck and Glueck, 1950; McCord and McCord, 1959; Andry, 1960), as they were in this sample.

Family transmission could account for both similarities and divergences. According to this hypothesis the similarities, those features of social background common to enuresis and delinquency, would have a pathway of transmission through the shared family culture. The divergence would arise from the differentiation of parental roles and their associations with these two forms of behaviour. The features special to enuresis would be transmitted chiefly through the performance of the mother in her childrearing role. The features special to delinquency would be transmitted chiefly through the performance of the father as the representative of the values of the adult world.

The concurrence of enuresis and delinquency in this sample of boys in approved school, however, is much greater than would be expected from the prevalence of enuresis in any social class in the community (Stein, Susser, and Wilson, 1965). In families where one parent is inadequate or hostile to stability, the second parent might also be expected to contribute to family disorder; this situation would lead to a high frequency of both enuresis and delinquency. Inadequacy of both parents could be the consequence of assortative mating by which inadequate individuals marry inadequate spouses (Slater and Woodside, 1951). It could also arise within an established marriage, and this is more probable (Kreitman, 1964; Nielsen, 1964; Hare and Shaw, 1965; Buck and Ladd, 1965). No two-way relationship within the nuclear family is independent of any other. Where one set of two-way relations is disturbed, as between mother and child, other relations between family members are likely to be disturbed as well.

\section{ENURESIS AND Situation}

The remission of bedwetting in the sickbay confirms that bedwetting habits vary with changes in situation. Multifarious changes that appear to lead to remission can be found in case-histories, and it has been difficult to isolate specific ones. In this instance, although the physical surroundings in the sickbay were not precisely the same as in the dormitory, we are inclined to look for the cause of the remissions in the change of social environment. In the sickbay, relations between boys and staff are more individual than elsewhere in approved schools, and relations between boys may be fewer, simpler, and easier to manage.

Our finding appears to contradict a clinical impression that sickness at home and in hospital can precipitate bedwetting in children who have achieved bladder control. The apparent contradiction perhaps arises from the level of anxiety attached to sickness, which may vary between children living at home and children living in approved schools. In both situations sickness brings about a social position of dependence; it can also bring about feelings of dependence, and behaviour that has been inter- 
preted as infantile regression (Lewin, 1951; Parsons and Fox, 1952). Sickness at home and in hospital, however, often seems to generate an increase in anxiety, at home transmitted from parents, and in hospital caused by separation from the home. By contrast, the sickbay in the approved school can supply adult figures, otherwise lacking, who offer emotional security, assuage the needs of dependence, and thus reduce anxiety. The change in bedwetting habits in the sickbay was not a consequence of a process of simple transference to a mother-figure, for the sickbay from which the records were obtained was in the sole charge of a male nurse who will have had to represent the mother-surrogate.

We are at a loss to interpret a number of our findings: for instance, the frequency of criminal records among the families of enuretic boys before admission, and the low IQs of senior enuretic boys. Some which were not included with our initial postulates relating to maternal deprivation and behaviour may be chance associations among many tested. Most of the other findings can be brought together, however, by the postulate that in a number of cases enuresis is the involuntary manifestation of persistent anxiety, and that such anxiety can be induced by insecure maternal relations. Weigl (1938) studied a group of 800 children attending the Bucharest Child Guidance Clinic for "nervous symptoms", and found that anxiety was the only symptom positively associated with enuresis. Weigl's conclusion must be treated with caution, because the population studied, like any other referred for treatment, was selected for psychiatric disorder, but other studies (already cited) provide evidence of a connexion between enuresis and nervous symptoms such as tics, nail-biting, and tantrums. Measures of anxiety in enuretic children are needed to substantiate the hypothesis.

\section{SUMMARY}

Boys in approved schools were shown to have a higher prevalence of enuresis than boys of the same age attending day schools in the same locality.

Enuretic boys in approved schools, when compared with controls, came from similar social backgrounds; but more had mothers who had left their families through divorce, desertion, or separation.

In personality, enuretic boys were rated as submissive and lacking in dominance, leadership, and sex interest, as compared with controls.

It was found that enuresis regularly remitted when boys were admitted to the sickbay. This finding establishes that bedwetting habits vary with situational changes.
Hypotheses are advanced to link family experience, delinquency, and enuresis.

The Home Office gave us permission to visit and examine the records of the approved schools and we are grateful to the staffs of these institutions for their cooperation. We thank particularly Mr J. Vardy, O.B.E., for giving us access to his material, and $\mathrm{Mr} \mathbf{J}$. Wilson for his assistance with the sickbay records.

It is a pleasure to acknowledge our indebtedness to $\mathrm{Dr}$ A. M. Adelstein for help with statistics. Mrs M. K. Arnison extracted the information from the records and Mrs A. Fish helped with computing. We thank our colleagues in the Department of Social and Preventive Medicine for their vigorous criticism and Prof. C. F. Brockington for his consistent support.

\section{REFERENCES}

Andry, R. G. (1960). "Delinquency and Parental Pathology". Methuen, London.

Blomfield, J. M., and Douglas, J. W. B. (1956). Lancet, 1,850 .

Buck, C. W., and Ladd, K. L. (1965). Brit. J. Psychiat., $111,587$.

Burlingham, D., and Freud, A. (1944). "Infants without Families". Allen and Unwin, London.

Burt, C. (1944). "The Sub-normal School-child", vol. 1: The Young Delinquent, 4th ed. University of London Press, London.

Clinard, M. B. (1962). Brit. J. Criminol., 3, 110.

Ekbald, M. (1948). Acta psychiat.neurol. scand., Suppl. 49.

Ferguson, T. (1962). "The Young Delinquent in his Social Setting". Oxford University Press, London.

Finney, D. J., Latscha, R., Bennett, B. M., and Hsu, P. (1963). "Tables Testing Significance in a $2 \times 2$ Contingency Table". University Press, Cambridge.

Glueck, S., and Glueck, E. T. (1950). "Unraveling Juvenile Delinquency". Harvard University Press, Cambridge, Mass.

Hallgren, B. (1956). Acta psychiat. neurol. scand., 31, $379,405$.

Hare, E. H., and Shaw, G. K. (1965). Brit. J. Psychiat., $111,461,467$.

Harnack, G. A. von (1953). Bibl.paediat. (Basel), Fasc. 55.

Healy, W., and Bronner, A. F. (1936). "New Light on Delinquency and its Treatment". Yale University Press, Newhaven, Conn.

Hirsch, N. D. M. (1937). "Dynamic Causes of Juvenile Crime". Science-Art Pub., Cambridge, Mass.

Kendall, M. G. (1952). "The Advanced Theory of Statistics", 5th ed. Griffin, London.

Kreitman, N. (1964). Brit. J. Psychiat., 110, 159.

Lewin, K. (1951). "Field Theory in Social Science". Harper, New York.

Mannheim, H. (1948). "Juvenile Delinquency in an English Middletown". Routledge and Kegan Paul, London.

McCord, W., and McCord, J. (1959). "Origins of Crime". Columbia University Press, New York.

Michaels, J. J., and Goodman, S. E. (1939). Amer. J. Orthopsychiat., 9, 59.

Miller, F. J. W., Court, S. D. M., Walton, W. S., and Knox, E. G. (1960). "Growing up in Newcastle upon Tyne". Oxford University Press, London.

Nielsen, J. (1964). Brit. J. Psychiat., 110, 683. 
Parsons, T., and Fox, R. (1952). J. soc. Issues, 8, no. 4, Stein, Z. A., Susser, M. W., and Wilson, A. E. (1965) p. 31 .

Slater, E., and Woodside, M. (1951). "Patterns of Marriage". Cassell, London.

"Families of Enuretic Children". Dev. med. and child neurol. (In the press).

Weigl, E. (1938). Z. Kinderpsychiat., 5, 103.

\section{APPENDIX I}

\author{
Last School Attended \\ Health \\ Weight \\ Height \\ Past lliness \\ Hospital Admission: \\ age at first admission \\ duration of first admission \\ Family \\ Age of mother at birth of subject \\ Age of father at birth of subject \\ Size of sibship \\ Rank of subject in family \\ Composition of Current Domestic Unit \\ Mother: death; desertion, separation, divorce*; \\ prolonged absence. \\ Father: death; desertion, separation, divorce; \\ prolonged absence. \\ Separation from Home \\ Age at onset \\ Duration \\ Nature of substitute home \\ Occupation of Father \\ Current employment status of father \\ Occupation of Mother \\ Current employment status of mother \\ Police Record of Subjects and Families \\ Convictions against parents \\ Convictions against sibs \\ Number of previous court appearances \\ Number of previous sentences \\ * Number of previous probation orders \\ Number of previous committals to remand home \\ Number of previous committals to Detention Centre \\ or Attendance Centres
}

ATTRIBUTES COMPARED OF 78 ENURETIC BOYS AND 78 CONTROLS
Number of previous committals to Approved Schools

Number of previous conditional discharges

Number of previous fines

Age at first court appearance.

First Offence:

Nature of crime

Type of goods stolen in cases of larceny

Number of accomplices

Present Offence:

*Nature of crime

Type of goods stolen in case of larceny

Number of accomplices

Number of cases taken into consideration

Stealing from the home

Psychologists' Reports

(o) Intellectual Ratings

Mechanical Arithmetic Age

WISC Verbal, Performance,* Full-scale*

Raven's Progressive Matrices

Terman Merrill IQ

(b) Behaviour Ratings: Numbers rated

Self-confidence $\begin{array}{cc}7 & 7 \\ \text { Enuretic } & \text { Contro }\end{array}$

Withdrawal $31 \quad 30$

Anti-social acts 7

Tidiness $\quad 7$

*Sex interest $\quad 31 \quad 30$

Self-expression 77

tDominance $\quad 31 \quad 30$

*Submissiveness $31 \quad 30$

Acceptance $\quad 31 \quad 30$

†Leadership $31 \quad 30$

Co-operation $31 \quad 30$

$\begin{array}{lll}\text { Antagonism } & 7 & 7\end{array}$

*Signifies significant difference $(P<0.05)$ between Enuretic Boys and Controls

t Level of significance was $<0.10>0.05$ when individual trait was compared, but $<0.05$ when combined with associated traits (Table VII).

\section{APPENDIX II}

Association between Dominance and Leadership in Thirty Controls (see Table VI for scale)

\begin{tabular}{|c|c|c|c|}
\hline $\begin{array}{l}\text { Dominance } \\
\text { (D) }\end{array}$ & $\begin{array}{l}\text { Leadership } \\
\text { (L) }\end{array}$ & Observed & Expected \\
\hline $\begin{array}{l}\text { High } \\
\text { High } \\
\text { Low } \\
\text { Low }\end{array}$ & $\begin{array}{l}\text { High } \\
\text { Low } \\
\text { High } \\
\text { Low }\end{array}$ & $\begin{array}{r}17 \\
6 \\
1 \\
6\end{array}$ & $\begin{array}{r}13 \cdot 8 \\
9 \cdot 2 \\
4 \cdot 2 \\
2 \cdot 8\end{array}$ \\
\hline Total & . & 30 & 30.0 \\
\hline
\end{tabular}

The numbers expected were calculated from the observed number, as follows:

$$
\begin{aligned}
& \mathrm{pD}=\text { High }=\frac{23}{30}, \quad \mathrm{pD}=\text { Low }=\frac{7}{30} \\
& \mathrm{pL}=\text { High }=\frac{18}{30}, \quad \mathrm{pL}=\text { Low }=\frac{12}{30}
\end{aligned}
$$

The association between (D) and ( $L$ ) is greater than would be expected by chance.

$$
\left(\chi^{2}=\frac{(0-E)^{2}}{E}=7.921 \text {, with } 3 \text { d.f.; } P<0.05\right)
$$


Association between Dominance, Submissiveness, and Leadership in 31 Enuretic Subjects (see Table VI for scale)

\begin{tabular}{|c|c|c|c|c|}
\hline $\begin{array}{l}\text { Domi- } \\
\text { nance } \\
\text { (D) }\end{array}$ & $\begin{array}{l}\text { Submis- } \\
\text { siveness } \\
\text { (S) }\end{array}$ & $\begin{array}{l}\text { Leader- } \\
\text { ship } \\
\text { (L) }\end{array}$ & $\begin{array}{l}\text { Ob- } \\
\text { served }\end{array}$ & Expected \\
\hline $\begin{array}{l}\text { High } \\
\text { High } \\
\text { High } \\
\text { High } \\
\text { Low } \\
\text { Low } \\
\text { Low } \\
\text { Low }\end{array}$ & $\begin{array}{l}\text { High } \\
\text { High } \\
\text { Low } \\
\text { Low } \\
\text { High } \\
\text { High } \\
\text { Low } \\
\text { Low }\end{array}$ & $\begin{array}{l}\text { High } \\
\text { Low } \\
\text { High } \\
\text { Low } \\
\text { High } \\
\text { Low } \\
\text { High } \\
\text { Low }\end{array}$ & $\begin{array}{r}10 \\
6 \\
0 \\
0 \\
0 \\
8 \\
0 \\
7\end{array}$ & $\begin{array}{l}4 \cdot 0 \\
8 \cdot 4 \\
1 \cdot 1 \\
3 \cdot 8 \\
1 \cdot 1 \\
7 \cdot 9 \\
2 \cdot 2 \\
2 \cdot 5\end{array}$ \\
\hline Total & & .. & 31 & $31 \cdot 0$ \\
\hline
\end{tabular}

The numbers expected were calculated from the observed numbers as follows:

$$
\begin{aligned}
& \mathrm{pD}=\text { High }=\frac{16}{31}, \quad \mathrm{pD}=\text { Low }=\frac{14}{31} \\
& \mathrm{pS}=\text { High }=\frac{24}{31}, \quad \mathrm{pS}=\text { Low }=\frac{7}{31} \\
& \mathrm{pL}=\text { High }=\frac{10}{31}, \quad \mathrm{pL}=\text { Low }=\frac{21}{31}
\end{aligned}
$$

The association between (D), (S), and (L) is greater than would be expected by chance.

$$
\left(\chi^{2}=\frac{(0-E)^{2}}{E}=25 \cdot 8 \text {, with } 7 \text { d.f.; } P<0 \cdot 001\right)
$$

